Hanna Karaszewska ${ }^{1}$ (iD) http:/orcid. org/0000-0002-7250-8722

Uniwersytet im. Adama Mickiewicza w Poznaniu

\title{
MEDIACJA JAKO POZASĄDOWA METODA ROZWIĄZYWANIA SPORU - PERSPEKTYWA HISTORYCZNA I WSPÓŁCZESNA
}

\section{Mediation as an Out-of-Court Dispute Resolution Method: A Historical and Contemporary Perspective}

Summary: Mediation is a process based on the principle of voluntariness, which should lead to resolve the conflict between the parties. As a form of intervention in a dispute, gives possibility to communicate between the parties without the participation of the court. The solutions developed during the mediation procedure direct the parties towards the future and allow to satisfy the interests of both sides. The work raises the problem of the historical conditions for the creation of mediation, its definition over the centuries. The article also describes arbitration courts as those that have settled disputes from the past to modern times. First of all, the article focuses on mediation, its essence, and the possibilities of applying it in individual countries. Mediation is presented as an important method, allowing parties to decide how to resolve a conflict. The article contains information on the history of her development, as well as legal bases that gave rise to its dissemination in the country and in the world. The historical conditions for the creation of mediation, the principles of mediation as well as the basic problems that arise during its conduct are described.

Keywords: mediation, conflict, dispute, arbitration, agreement, settlement, mediator

1 Dr Hanna Karaszewska, Uniwersytet im. Adama Mickiewicza w Poznaniu, Wydział Studiów Edukacyjnych, Zakład Resocjalizacji; ul. Szamarzewskiego 89, 60-568 Poznań; e-mail: hkuam@ amu.edu.pl. 


\section{Wprowadzenie}

Jednym ze sposobów podejścia do konfliktu jest poszukiwanie rozwiązań, które pozwolą nie tyle zażegnać konflikt, ile przede wszystkim stworzyć możliwość zauważenia w nim ludzi - ich potrzeb i wartości. Drogą do sukcesu może być mediacja, która pozwala na dostrzeganie $\mathrm{w}$ konflikcie/sporze ${ }^{2}$ wartości mobilizującej do działania i podejmowania decyzji w życiowych kwestiach. Postrzeganie konfliktu przez pryzmat wyłącznie negatywny nie jest współcześnie zasadne. Specjaliści z zakresu mediacji podkreślają, że choć bywają one trudne i z perspektywy stron niemożliwe do rozwiązania, to praktyka mediacyjna pokazuje, że porozumienie jest osiągalne, ale wymaga pracy i poświęcenia drugiej osobie uwagi. Mediacja nie jest panaceum na wszystkie spory, nie zawsze kończy się „sukcesem" w postaci porozumienia czy ugody, ale jest to procedura, z której warto i trzeba korzystać, gdyż pozwala ona na oddanie sporu w ręce stron - czyli jednostek najbardziej zainteresowanych jego rozwiązaniem. I choć to one decydują, czy chcą w ten sposób rozwiązać problem, to konieczne jest funkcjonowanie w tej relacji także niezależnej osoby - jaką stanowi mediator. Spotkanie między stronami tworzy tzw. przestrzeń komunikacyjną ${ }^{3}$, w której mogą oni w nieskrępowany sposób porozmawiać o kwestiach spornych, o faktach, uczuciach i sposobie dalszego funkcjonowania. Konflikty, jak pisze Adam Zienkiewicz, nie tylko antagonizują, ale także potrafią spajać jednostki i świadczą o dynamice zmian i rozwoju społeczności. Mogą działać konstruktywnie albo wypełniać funkcje destrukcyjne $e^{4}$. Socjologiczne ujęcie konfliktu wskazuje na dwa podejścia teoretyczne do tej problematyki. Pierwsze, obecne w refleksji Emile’a Durkheima, Talcotta Parsonsa czy Roberta Mertona, podkreśla znaczenie konsensusu i równowagi, dlatego konflikty postrzegane są jako szkodliwe i destrukcyjne ${ }^{5}$. Widoczne jest tu traktowanie ich jako stanu patologii, który zakłóca równowagę systemu społecznego. W drugim podejściu, którego reprezentantami są: Georg Simmel', Ralf Dahrendorf, Max Weber oraz Lewis A. Coser, widoczne jest traktowanie ich jako elementu rozwoju społecznego i zmiany. „Konflikty pomagają jednostkom i grupom społecznym w identyfikacji ich miejsca i roli w danej strukturze społecznej, powodują ich aktywność, wpływają na modyfikację, bądź kreację

2 Spór jest jednym ze stadiów konfliktu i stanowi jego kwalifikowaną odmianę. Jeśli strony ujawniają na forum społecznym sprzeczne interesy, dochodzi wówczas do przekształcenia konfliktu w spór. Adam Zienkiewicz, Studium mediacji. Od teorii ku praktyce (Warszawa: Difin, 2007), 22.

3 Paweł Szczepaniak, Sprawiedliwość naprawcza w resocjalizacji więźniów (Warszawa: Uniwersytet Warszawski. Instytut Profilaktyki Społecznej i Resocjalizacji, 2016), 304.

4 Zienkiewicz, Studium mediacji..., 21.

5 Emile Durkheim, Socialism and Saint Simone (London: Routledge \& New Haven: Kegan Paul, 1959), 44.

6 Georg Simmel, Socjologia (Warszawa: PWN, 1975), 26-30. 
nowych społecznych rozwiązań, relacji czy wartości”' Cytowane słowa jednoznacznie wskazują na konieczność dostrzeżenia w konflikcie szansy na zmianę, którą wprowadzić może skorzystanie z procedury mediacji. Nie jest to jedyna forma rozwiązania sporu, można bowiem skorzystać z arbitrażu, który jest postępowaniem rozjemczym, polubownym, jest też alternatywą wobec kosztownego, a przede wszystkim czasochłonnego sądownictwa powszechnego. Słowo „arbitraż" pochodzi od łacińskiego słowa arbitrarium, -ii, oznaczającego sąd polubowny ${ }^{8}$. Sądownictwo polubowne/arbitraż $\dot{z}^{9}$ to przewidziany przez prawo sposób rozstrzygania sporów przez tzw. sąd polubowny, czyli organ, który jest uprawniony do działania przez umowę stron. Sądy polubowne funkcjonują poza systemem sadownictwa powszechnego, są niezależne od sądów powszechnych, ale wyroki mają równą moc prawną ${ }^{10}$. Mediacja wywodzi się natomiast $\mathrm{z}$ greckiego terminu medos, czyli pośredniczący, neutralny, nieprzynależny do żadnej ze stron, a także z łacińskiego słowa mediare, czyli być w środku, pośredniczyć w sporze, oraz mediatio - pośrednictwo. Arbitraż nastawiony jest przede wszystkim na szybkie osiągnięcie wyniku, nie uwzględnia procesu toczącego się między stronami. Mediacja natomiast bierze pod uwagę relacje pomiędzy stronami i etap rozwoju ich konfliktu ${ }^{11}$.

Celem artykułu jest ukazanie historycznych uwarunkowań mediacji, początków jej stosowania oraz aktualnej podstawy prawnej i praktyki postępowania w Polsce. Treść artykułu prezentuje sposoby rozwiązywania konfliktów, najpierw za pomocą sądów polubownych, a następnie mediacji. Przedstawienie mediacji z perspektywy historycznej, wskazanie na jej stosowanie w przeszłości, pokazuje, jak ważną funkcję spełniała w konfliktach międzyludzkich, jak ewoluowała na przestrzeni wieków i lat.

7 Adam Zienkiewicz, Studium mediacji..., 22.

8 Janusz Sondel, Słownik łacińsko-polski dla prawników i historyków (Kraków: Universitas, 2003); Słownik języka polskiego, red. nauk. Mieczysław Szymczak (Warszawa: PWN, 1998), 69.

9 „W języku prawniczym odróżnia się pojęcie arbitraż od pojęcia sąd polubowny (chociaż co do zasady traktuje się je synonimicznie), dla oznaczenia sądów polubownych rozstrzygających spory gospodarcze tak w krajowym, jak i międzynarodowym obrocie handlowym [...].Wśród podstawowych form ADR arbitraż jest najstarszy i najbliższy tradycyjnemu sądownictwu państwowemu [...]. Wyroki arbitrażowe (sądów polubownych) wielokrotnie bywają wydawane na podstawie kryteriów pozaprawnych (orzekane na zasadach słuszności - amiable compositeur/ex aequo et bono)", Zienkiewicz, Studium mediacji..., 57-58.

10 Agnieszka Rękas, Czy tylko sąd rozstrzygnie o sporze? Mediacja i sądownictwo polubowne. Informator o alternatywnych sposobach rozwiązywania sporów (Warszawa: Europejski Fundusz Społeczny, 2010), 63.

11 Maria J. Zajączkowska, „Sposoby komunikowania się mediatora ze stronami w przyjętych strategiach mediacyjnych". W: Rozwiązywanie sytuacji konfliktowych $w$ wymiarze jednostkowym i społecznym, red. Martyna Plucińska (Poznań: Wydawnictwo Naukowe Wydziału Nauk Społecznych Uniwersytetu im. Adama Mickiewicza, 2014), 329. 


\section{Sądy polubowne i mediacja - etiologia}

Doświadczanie konfliktów nie jest domeną naszych czasów, nie jest przypisane do konkretnej kultury czy państwa. Ludzie zawsze doświadczali sporów, ale ich rozwiązywanie świadczyło o pewnej dojrzałości i wpływało na bezpieczeństwo ogółu. To właśnie ono nakazywało zwaśnionym stronom zakończyć spór. Formy, które można nazwać zbliżonymi do mediacji, występowały - jak piszą Jerome T. Barrett i Joseph P. Barrett ${ }^{12}$ - już w najdawniejszych czasach, natomiast samą mediację praktykowano w kulturze żydowskiej, chrześcijańskiej, buddyjskiej, hinduskiej, konfucjańskiej, w państwach islamu ${ }^{13}$. Mediacja stosowana była w państwie Sumerów w Mezopotamii w IV tysiącleciu p.n.e. Jak pisze Marta Wysocka-Fronczek, przed tradycyjnym rozwiązaniem sporu przez radę pełniącą funkcję sądów sprawa była przedstawiona tzw. maszkimowi. Była to osoba pełniąca funkcję komisarza w państwie Sumerów, której zadaniem było mediowanie między skonfliktowanymi stronami w celu polubownego zakończenia sprawy ${ }^{14}$.

Pomoc w rozwiązywaniu sporu uzyskiwano zazwyczaj od osób niezależnych, które wysłuchując sprawy stron, wydawały decyzję o jego zakończeniu. Warunkiem scedowania decyzji na konkretną osobę był szacunek, którym cieszyła się dana osoba. Wyrok wydawany był również przez władcę, sędziego czy arbitra. Arbitrami lub mediatorami w przypadku zaistnienia sporu były osoby, które określano mianem przyjaciela, dobrego człowieka, a także zacnego obywatela. Historia rozstrzygania sporów za pomocą arbitra wskazuje, że była to zazwyczaj osoba będąca autorytetem w danej dziedzinie, osoba, która powoływana była przez strony w celu rozstrzygnięcia sporu. Arbitraż jako sposób rozwiązywania konfliktu obecny był już w praktyce $\mathrm{w} \mathrm{V}$ wieku p.n.e. i zdecydowanie można stwierdzić, że powstał on wcześniej niż sądownictwo państwowe ${ }^{15}$.

Mamy wszakże przesłanki znacznie starsze w tym zakresie. W XVIII wieku p.n.e. wspomnienie o polubownym rozwiązaniu sporu (rozjemstwie) zostało umieszczone

12 Jerome T. Barrett, Joseph P. Barrett, A History of Alternative Dispute Resolution (San Francisco: CA: John Wiley and Sons, Inc., 2004), 1-18.

13 Jak podaje Stanisław Kordasiewicz, jeden z mediatorów - Fabio Chigi, który pracował nad zawarciem pokoju westfalskiego, w 1644 roku otrzymał konkretną instrukcję od papieża, w jaki sposób prowadzić rozmowy ze stronami. Sporządzając notatkę, która zawierała zasady prowadzenia mediacji, uwzględnił: neutralność, poufność i bezstronność, a zatem zasady, które obowiązują w mediacji we współczesnych czasach. Stanisław Kordasiewicz, „Historyczna i międzynarodowa perspektywa mediacji”. W: Mediacje. Teoria i praktyka, red. Ewa Gmurzyńska, Rafał Morek (Warszawa: Wolters Kluwer Polska, 2014), 35.

14 Marta Wysocka-Fronczek, „Dlaczego kieruję sprawy do postępowania mediacyjnego?”, Prokuratura i Prawo 2 (2011), 145.

15 Krzysztof Falkiewicz, Radosław L. Kwaśnicki, „Arbitraż i mediacja w świetle najnowszej nowelizacji Kodeksu postępowania cywilnego", Przegląd Prawa Handlowego 11 (2005), 32; Łukasz Mroczyński-Szmaj, „Arbiter i arbitraż - na przestrzeni dziejów. Historia polskiego sądownictwa polubownego do 1989 r.", Zeszyty Naukowe Uniwersytetu Rzeszowskiego. Seria Prawnicza. Prawo 14 (82) (2014). 
nawet w bardzo srogim kodeksie Hammurabiego. Wówczas sędziami byli kapłani, którzy następnie stali się właściwymi sędziami polubownymi; do nich, jak wskazują dokumenty, odsyłali królewscy urzędnicy sądowi sprawy do osądzenia - pomimo iż ich orzeczenie podlegało rewizji sądów królewskich ${ }^{16}$.

Sama instytucja wywodzi się z prawa rzymskiego, które wskazywało, że strony zawierały umowę o powierzeniu rozstrzygnięcia sporu osobie prywatnej. W prawie rzymskim obywatele, którzy chcieli rozwiązać spór poza udziałem państwa, mogli powierzyć zatem swój konflikt osobie trzeciej. Wówczas odbywało się nieformalne postępowanie przed ustanowionym przez strony sędzią polubownym. Takie postępowanie znane było już w okresie przedklasycznym, natomiast w okresie klasycznym zapis na sąd polubowny sporządzały strony w momencie nieformalnego porozumienia, które jednocześnie było podstawą działania dla arbitra (compromissum). W okresie tym władza arbitra była podobna do stanowiska sędziego w procesie toczącym się z actio in aequum concepta ${ }^{17}$. Można było również zawierać dodatkowe nieformalne porozumienie, które określane było mianem receptum arbitra. Oznaczało to, że arbiter dobrowolnie przyjął na siebie funkcję. Jednocześnie zobowiązał się do rozstrzygnięcia sporu pod rygorem zapłaty grzywny (multae dictio) lub skonfiskowania określonych przedmiotów. W okresie poklasycznym - compromissum zawierane było w drodze nieformalnego porozumienia (pactum $)^{18}$. Taki sposób rozwiązania sporu odznaczał się sprawnością, szybkością i mniejszymi kosztami.

Z kolei historyczne uwarunkowania arbitrażu greckiego wskazują np. na konieczność zapisania się stron na tzw. sąd polubowny oraz możliwość wyboru sędziów polubownych. Sędziowie ci mogli być również losowani z listy, którą państwo sporządzało każdego roku. Wymogi dotyczące sędziego dotyczyły ukończenia przez niego 30. roku życia oraz posiadania pełni praw obywatelskich (nie mogła być nim osoba, której czasowo odebrano prawa ze względu na czyn hańbiący) ${ }^{19}$. Arbitraż grecki stanowi pierwowzór arbitrażu rzymskiego, który określany jest mianem najbardziej zaawansowanej postaci antycznego arbitrażu.

Z kolei w Egipcie w VI wieku n.e. porozumienia między stronami spisywano na zwojach papirusu, które - zachowane na przestrzeni wieków - pozwalają stwierdzić, że konflikty, które powstawały między ludźmi, rozwiązywane były poza sądami. Istniała zatem możliwość przekazania własnej sprawy arbitrowi i wówczas strony zawierały umowę zobowiązującą je do zastosowania się

16 Mroczyński-Szmaj, „Arbiter i arbitraż...”, 131.

${ }_{17}$ Mieczysław Żołnierczuk, Rzymskie sądownictwo polubowne (okres przedklasyczny i klasyczny) (Lublin: UMCS, 1978), 25.

${ }^{18}$ Renata Świrgoń-Skok, Aneta Arkuszewska, „Wpływ alternatywnych sposobów rozwiązywania sporów na efektywność ochrony prawnej”, Zeszyty Naukowe KUL 60 (2017), 3 (239), 248.

${ }_{19}$ Marian A. Myrcha, Sądy polubowne w prawie kanonicznym. Studium prawno-porównawcze (Lublin: Rozprawy Wydziału Kanoniczno-Teologicznego KUL, 1948), 9. 
do decyzji/wyroku arbitra. Na jej podstawie następowała egzekucja wyroku arbitrażowego. W porozumieniu występował napis grecko-łaciński, a mianowicie kompromisson. Innym sposobem rozwiązywania sporu było zawarcie ugody, którą w dokumentach nazywano dialysis. W tym przypadku strony opisywały swój konflikt, jego etiologię, a także wszelkie podjęte próby pojednania. Wskazywały również na osoby trzecie, które pomagały im w zawarciu porozumienia. Próby dojścia do porozumienia, mediację, w której uczestniczyli przyjaciele oraz cenieni obywatele, określano mianem mesiteia. Strony, które doszły do porozumienia, zobowiązywały się i deklarowały odstąpienie od skarg sądowych. Ugoda zazwyczaj była skuteczna, gdyż w sytuacji zerwania, niewykonania groziły wysokie kary pieniężne. Zabezpieczano się również za pomocą złożenia przysięgi ${ }^{20}$. W przypadku dialysis możliwa jest interpretacja, iż mogła to być tzw. mediacja ocenna - czyli spór rozstrzygany przez osoby trzecie, które pełniły funkcję mediatora. W Egipcie arbitrami i mediatorami były osoby godne zaufania, posiadające autorytet, byli nimi też znawcy prawa. Strony wybierały tę formę rozwiązywania konfliktów, ponieważ stanowiła bardziej atrakcyjny sposób niż sąd.

Z kolei zastosowanie mediacji widoczne jest w państwach azjatyckich, w których wynikała ona poniekąd z kultury i religii. Dominowało przekonanie o konieczności poszukiwania rozwiązania w celu zachowania równowagi i harmonii w relacjach społecznych. Nie bez znaczenia były też nauki Konfucjusza dotyczące prawości, humanitarności, lojalności, altruizmu wobec ludzi. Konfucjusz propagował szczere i sumienne wypełnianie obowiązków wobec siebie ${ }^{21}$. W Chinach początki mediacji datuje się na około 2500 lat temu. Istniało przekonanie, że koncepcje filozoficzno-etyczne Konfucjusza ${ }^{22}$ będą podstawą do społecznego funkcjonowania człowieka. Zgodnie z myślą Konfucjusza rozwiązywanie konfliktów miało być oparte na następujących założeniach: prawa i roszczenia indywidualne mają mniejszą wartość niż uczucia i relacje w obrębie klanu; zasady etyczne są ważniejsze niż dobra materialne - a zatem bogaci powinni wspierać biednych, a silni słabszych. Potępieniu podlegały osoby, które odmawiały udzielenia pomocy innym. Harmonię powinno uzyskiwać się poprzez pożądany obraz życia rodzinnego i społecznego. Człowiek, unikając spraw sądowych, żył zgodnie z obowiązującymi zasadami etycznymi, a wchodząc na drogę sądową, zaprzeczał

20 Kordasiewicz, „Historyczna i międzynarodowa perspektywa..., 36-37.

21 Xinzhong Yao, Konfucjanizm. Wprowadzenie (Kraków: Wydawnictwo Uniwersytetu Jagiellońskiego, 2009), 183. Szerzej także: Pamela Klityńska, „Myśl Konfucjusza”, ACTA ERASMIANA XIII 76 (2016); Roman Sławiński, Konfucjanizm i jego współczesne interpretacje (Warszawa: ASKON, 2013); Michał Sobieraj, Filozofia Konfucjusza, wersja PDF (Olsztyn 2005).

${ }^{22}$ „Za czasów Konfucjusza rozstrzygnięcie sporu przez organ sądowy uważano jako »drugi najlepszy sposób rozwiązywania sporów«. Natomiast bardzo ceniono sobie w tym okresie powszechnie stosowaną drogę rozwiązywania sporów przez tzw. pośrednika. Osoba pośrednika przekazywała informacje i oferty stronom konfliktu tak długo, aż same doszły do rozwiązania sporu w sposób najbardziej im odpowiadający. Jego zadaniem było, podobnie jak we współczesnej mediacji, ułatwienie stronom rozwiązania sporu”. Wysocka-Fronczek, „Dlaczego kieruję sprawy..., 146. 
harmonii w relacjach międzyludzkich. Każdy proces sądowy świadczył o braku dobrych relacji jednostki ze społecznością, dlatego chińscy urzędnicy starali się doprowadzać do ugody, zanim wszczęto postępowanie sądowe ${ }^{23}$. Rozwój mediacji podyktowany był również obawą przed utratą twarzy, a w związku z tym utratą godności i szacunku. Mediacja, która prowadzona była przez zaufane osoby, stanowiła po prostu formę ochrony przed jej utratą. Jak podaje Stanisław Kordasiewicz, za panowania dynastii Qing procedura rozwiązywania konfliktów podzielona została na trzy etapy, podczas których mogło dojść do mediacji. Pierwszy etap zakładał podjęcie próby zawarcia porozumienia między stronami przed wniesieniem sprawy do urzędnika. Pomocą służył naczelnik rodu lub najważniejsza osoba $\mathrm{w}$ wiosce. Na tym etapie część spraw była rozwiązywana i dochodziło do zawarcia ugody. Drugi etap - to możliwość odesłania stron do mediacji przez urzędnika, do którego wniesiono sprawę. Mediacja przeprowadzana była przez naczelnika wioski lub głowę rodu. Na trzecim etapie mediacje prowadził już sam urzędnik, a sprawy skierowane do mediacji określano mianem wyższej wagi czy tych, które nie zakończyły się porozumieniem w obrębie wioski ${ }^{24}$.

Podobnie jak w Chinach, również w Japonii rozwój mediacji wynikał z wysoko cenionej harmonii społecznej i chęci rozwiązania sporu na gruncie porozumienia i szacunku. Taka postawa społeczna ma swoje uzasadnienie w religii buddyjskiej oraz myśli konfucjańskiej. Mediacja była mniej czasochłonna niż podróż do sądu, zdecydowanie tańsza, a przede wszystkim odpowiadała nauce Konfucjusza ${ }^{25}$.

Mediacja stosowana była również w kulturze wczesnochrześcijańskiej, o czym świadczy fakt przejmowania i przyjmowania przez duchownych niektórych przestępców i świadczenie przez osoby duchowne funkcji „rozjemców” pomiędzy podejrzanym a władzą. Duchowni często stawali się również mediatorami w sprawach rodzinnych oraz brali udział jako mediatorzy w dyplomatycznych sporach ${ }^{26}$.

Mediacja była jedną z podstawowych form rozwiązywania sporów zarówno w Azji, Europie, jak i Afryce. Sąd stanowił ostateczność, traktowano go czasem jako wstydliwą instancję i wykorzystywano dopiero wówczas, gdy inne możliwości rozwiązania konfliktu zawiodły. Praktyczne zastosowanie mediacji w Europie potwierdzone zostało dokumentami pisanymi od początku IX wieku. Dominujące było postępowanie arbitrażowe, a mediacja pozostawała w cieniu tego postępowania.

Najwięcej dokumentów potwierdzających zastosowanie mediacji dotyczy konfliktów politycznych, które w historii Europy przez długi czas były bezpośrednio powiązane

${ }^{23}$ Szerzej na ten temat: Ewa Gmurzyńska, Mediacja w sprawach cywilnych w amerykańskim systemie prawnym. Zastosowanie w Europie i w Polsce (Warszawa: C.H. Beck, 2007).

24 Kordasiewicz, „Historyczna i międzynarodowa perspektywa...”, 42.

25 Ronda Roberts Callister, James A. Wall, Jr, „Japanese Community and Organizational Mediations", The Journal of Conflict Resolution 2 (41) (1997), 313-314.

${ }^{26}$ Wysocka-Fronczek, „Dlaczego kieruję sprawy...”, 146. 
ze sporami pomiędzy panującymi dynastiami czy rodzinami arystokratycznymi. Pokój o charakterze politycznym był więc często powiązany z pokojem w obrębie danej rodziny królewskiej. Najwcześniejszym zachowanym świadectwem rozwiązania konfliktu przez mediację jest konflikt Karolingów pomiędzy następcami Karola Wielkiego, w którym król Ludwik Niemiecki (843-876) pełnił rolę mediatora i określał siebie jako privatus mediator ${ }^{27}$.

W Europie istotną rolę w prowadzeniu mediacji w konfliktach politycznych odegrał Kościół i to właśnie z nim wiążą się dokumenty, które odróżniały postępowanie sądowe, arbitrażowe i mediację. Osoba mediatora traktowana była nie jako sędzia czy jako arbiter, ale jako przyjaciel stron, który pomagał znaleźć dla nich akceptowalne rozwiązanie ${ }^{28}$.

Zatem na terenie Europy aż do końca XVI wieku dominowało postępowanie arbitrażowe. Dopiero w kolejnym wieku postępowanie polubowne „ustąpiło miejsca” mediacji w sprawach prowadzonych tytułem porozumień pokojowych oraz porozumień w sporach gospodarczych.

Z kolei w Polsce już w tradycji plemiennej znane były metody rozwiązywania sporów za pomocą ugody i pojednania. Formy te obowiązywały do końca średniowiecza. Wykorzystywane były, gdy: „sprawiedliwość wobec sprawców przestępstw realizowana była przy pomocy wróżdy rodowej (»krwawej zemsty«). Niekiedy stan wróżdy między rodami kończono ugodą zawieraną za pośrednictwem jednaczy. Jej podstawowymi elementami były okup oraz pokora, polegająca na symbolicznym akcie przyznania się do winy i prośbie o przebaczenie"29. Osoby pełniące funkcje jednaczy musiały być bezstronne, stosować zasadę poufności, a także stawiać się w wyznaczonym terminie. Jak piszą Adam Moniuszko i Anna Rosner $^{30}$, w późniejszych wiekach pojawiają się pewne trudności w poszukiwaniu źródeł mediacji w Polsce. Zalicza się do nich między innymi:

a. trudność rozróżnienia w prawie staropolskim wyroków sądu polubownego i ugód;

b. fakt, iż w I Rzeczypospolitej spór mógł się zakończyć na rozstrzygnięciu, które wydał arbiter, a także przez ugodę zawartą przez strony przy udziale mediatora;

c. występowanie różnic kulturowych i ustrojowych, które wpływały na rozumienie i stosowanie prawa.

Ustrój społeczny w Polsce, począwszy od średniowiecza aż do początku XIX wieku, opierał się na zasadzie stanowości. Oznaczało to, że każdy ze stanów miał

27 Kordasiewicz, „Historyczna i międzynarodowa perspektywa...”, 45.

28 Mroczyński-Szmaj, „Arbiter i arbitraż...”, 133.

29 Adam Moniuszko, Anna Rosner, „Historia polubownego rozwiązania sporów na ziemiach polskich. Zarys problematyki”. W: Mediacje. Teoria..., 56.

30 Tamże, 54-55. 
odrębne prawo i własne sądownictwo ${ }^{31}$. Funkcjonowały wówczas sądy miejskie, wiejskie czy kościelne i interpretacja prawa oraz jego stosowanie było tak różnorodne, że trudno mówić o sprawiedliwości postępowania ${ }^{32}$. Osoby określane mianem sędziów polubownych lub mediatorów wybierane były dowolnie. Strony wskazywały równą liczbę arbitrów, a także miały możliwość wskazania superarbitra, czyli mediatora, który jednak nie był powoływany obligatoryjnie. Postępowanie sądu polubownego było ostateczne, nie przysługiwało od niego odwołanie i kończyło się zawarciem ugody lub wydaniem wyroku. Katarzyna Sójka-Zielińska ${ }^{33}$ pisze, iż wraz z oświeceniowymi ideami kodyfikacyjnymi podjęto próby sformalizowania postępowania polubownego, ale do rozróżnienia prawnego arbitrażu i mediacji doszło dopiero w XIX wieku. Wówczas nastąpiły istotne zmiany w prawie, które wzorowane były na systemie francuskim. W każdym powiecie funkcjonował sąd pokoju, a w nim wydział pojednawczy. Próby zastosowania ugód podejmował się urzędnik sądu, a w przypadku ich osiągnięcia nabierały mocy prywatnego zobowiązania i uznawano je za tytuły egzekucyjne. Sądy pokoju uznawane były za kontynuację staropolskiego sądownictwa polubownego. Ugruntowała się rola nieformalnego rozjemcy, mediatora, jednacza ${ }^{34}$. Mediacja z czasem objęła różne dziedziny życia, stała się środkiem rozwiązywania konfliktów międzynarodowych ${ }^{35}$, a jej pełny rozwój nastąpił w latach 70 . XX wieku

${ }^{31}$ Szerzej na ten temat: Janusz Tazbir, Święci, grzesznicy i kacerze (Warszawa: Wiedza Powszechna, 1959); Jędrzej Kitowicz, Opis obyczajów za panowania Augusta III, oprac. R. Pollak (Wrocław: Wydawnictwo Zakładu Narodowego im. Ossolińskich, 1951); Zbigniew Kuchowicz, Obyczaje staropolskie XVII-XVIII wieku (Łódź: Wydawnictwo Łódzkie, 1975); Jan St. Bystroń, Dzieje obyczajów w dawnej Polsce. Wiek XVI-XVIII (Warszawa: Trzaska, Evert i Michalski, 1994); Roman Kaleta, Sensacje $z$ dawnych lat (Wrocław: Ossolineum, 1980).

32 Andrzej F. Modrzewski, Dzieła wszystkie. Mowy, t. II, red. Stefan Żółkiewski (Warszawa: Państwowy Instytut Wydawniczy, 1954), 45 i nast.

33 Katarzyna Sójka-Zielińska, Drogi i bezdroża prawa. Szkice z dziejów kultury prawnej Europy (Wrocław: Ossolineum, 2010), 55.

34 Szerzej na ten temat: Anna Rosner, „Sędziowie i urzędnicy sądów pokoju w Księstwie Warszawskim”, Przegląd Historyczny 4 (79) (1988), 659-682.

35 „Wielka Brytania była mediatorem pomiędzy Portugalią a Brazylią (1925 r.), Francja między Anglią i Grecją (1849 r.), Francja i Anglia pomiędzy Hiszpanią i Marokiem (1844 r.). Mediatorami byli papieże Leon XIII (1885 r.) w sporze pomiędzy Niemcami a Hiszpanią i prezydenci: Teodor Roosevelt (wojna rosyjsko-japońska) oraz Jimmy Carter w konflikcie między Izraelem i Egiptem (porozumienie w Camp David). [...] Rozwój nowych możliwości rozstrzygania sporów przyczynił się do powstania i stosowania nowych pojęć, takich jak: ADR - Alternative Dispute Resolution, rozumiane także jako Appropriate Dispute Resolution czy Amicable Dispute Resolution. Działania z zakresu ADR zostały sformalizowane w USA w 1913 roku, podczas gdy w Wielkiej Brytanii uchwalono tzw. „Conciliation Act” (Akt Pojednania) już w 1896 r. Pełnomocnicy w procesie pojednania powołali instytucję o nazwie United States Conciliation Service, która w 1947 r. została przemianowana na Federal Mediation and Conciliation Service. W międzyczasie, w roku 1926, powstała organizacja AAA - American Arbitration Association, świadcząca usługi z zakresu rozwiązywania sporów w prywatnym sektorze. Wiele amerykańskich Stanów posiada własne ustanowione programy, które umożliwiają wykorzystywanie mediacji do rozstrzygania sporów niemalże na każdej płaszczyźnie, włącznie ze sprawami rodzinnymi, związanymi ze środowiskiem oraz stosunkiem pracy. Podobny rozwój mediacji nastąpił w Australii, Nowej Zelandii oraz Kanadzie”. Wysocka-Fronczek, „Dlaczego kieruję sprawy...”, 147. 
w USA. Przyczyną tak intensywnego rozwoju mediacji w Stanach Zjednoczonych był kryzys sądownictwa. Była ona odpowiedzią na potrzeby obywateli, którzy przede wszystkim chcieli rozwiązać swoje konflikty poza sądem, poza postępowaniem sądowym, które było długotrwałe i czasochłonne. Dzięki mediacji jednostki mogły zyskać większy dostęp do sprawiedliwości. W latach 80 . XX wieku, pod wpływem harwardzkiego programu mediacyjnego, mediacja rozwijała się zarówno w teorii (szereg opracowań naukowych), jak i w praktyce. W 1995 roku wydany został w USA pierwszy informator dotyczący organizacji oraz usług mediacyjnych (Dispute Resolution Directory) ${ }^{36}$. „W wielu krajach dopiero z biegiem czasu - dzięki skuteczności w zakresie rozwiązywania sporów cywilnych i handlowych - mediacja zaczęła znajdować zastosowanie również $\mathrm{w}$ innych dziedzinach $[. .$.$] z zakresu prawa pracy, karnego i sądowo-administracyjnego oraz nie-$ których innych dziedzin, a dopiero stosunkowo niedawno - w 2005 r. - znalazła swoje miejsce w ramach postępowania cywilnego" ${ }^{37}$.

\section{Mediacja - aktualne rozwiązania w stosowaniu procedury mediacji w Polsce i sposób jej prowadzenia}

Doświadczenia w stosowaniu mediacji na przestrzeni wieków pozwalają na stwierdzenie, że obecnie mediacja jest najważniejszą postacią alternatywnych metod rozwiązywania sporów, nazwanych ADR (Alternative/Amicable Dispute Resolution), i często określana jest mianem „królowej ADR”. W Polsce mediacja trafiła do sądów karnych, rodzinnych i administracyjnych, a dopiero później zaczęto stosować ją w sporach gospodarczych. Ten tryb postępowania stwarza możliwość rozstrzygania sporów bez konieczności prowadzenia sformalizowanego postępowania sądowego ${ }^{38}$. Po 1995 roku powstały w Polsce ośrodki mediacji, które realizowały eksperymentalny program mediacji. Odbywała się ona między pokrzywdzonym i sprawcą czynu karalnego (nieletnim). Doświadczenie to pozwoliło na wprowadzenie w 1997 roku zmiany w kodyfikacji karnej. Wprowadzono mediację do Kodeksu postępowania karnego ${ }^{39}$. Następnie w sierpniu 1998 roku, na mocy Rozporządzenia Ministra Sprawiedliwości w sprawie warunków prowadzenia mediacji - w sprawach dorosłych sprawców przestępstw, a w maju 2001 roku w sprawach nieletnich. W dniu 21 stycznia 1998 roku na posiedzeniu Komitetu Rady Europy przyjęta została Rekomendacja nr R(98)1, zalecająca państwom

36 Kordasiewicz, „Historyczna i międzynarodowa perspektywa...”, 35 i nast.

37 Rafał Morek, Mediacja w sprawach cywilnych. Stan prawny na 1 grudnia 2012 r. (Warszawa: Ministerstwo Sprawiedliwości, 2012), 5.

38 Adam Zienkiewicz, „Mediator w sprawach cywilnych”, Rejent 5 (2005), 137-152.

39 Mediacja w sprawach karnych wprowadzona została w kodyfikacji postępowania karnego z 1997 roku. Następnie została rozszerzona ustawą o zmianie ustawy - Kodeks postępowania karnego z 10 stycznia 2003 roku (Dz.U. 1997, nr 17, poz. 155), art. 23a. 
członkowskim wprowadzenie oraz promowanie mediacji rodzinnych ${ }^{40}$. Duże znaczenie dla rozwoju tzw. kultury mediacji w Polsce miała nowelizacja Kodeksu postępowania cywilnego i innych ustaw w $2005 \mathrm{roku}^{41}$. Rozwiązania te dały możliwość mediacji w sprawach rodzinnych, gospodarczych i pracowniczych. Kolejne zmiany ukształtowały mediację $\mathrm{w}$ takiej formie, $\mathrm{z}$ jaką obecnie mamy do czynienia. Przepisy Kodeksu postępowania cywilnego wskazują na wyodrębnienie dwóch podstaw prowadzenia mediacji: umowy o mediację oraz postanowienia sądu o skierowaniu sprawy do mediacji. Można zatem wskazać na istnienie mediacji umownych i mediacji sądowych, które prowadzone są na podstawie skierowania sądu ${ }^{42}$.

Dzięki wprowadzanym na przestrzeni lat zmianom oraz doświadczeniom różnych państw stosujących mediację można obecnie stwierdzić, że jest ona procesem, który - oparty na zasadzie dobrowolności - powinien zmierzać do rozwiązania konfliktu pomiędzy stronami poprzez analizę jego przyczyn. Jest to też forma interwencji w spór ${ }^{43}$. Nie jest to forma terapii ani spotkanie, podczas którego mediator przekaże gotowe rozwiązania dla stron, nie jest to również poradnictwo ani arbitraż. Umożliwia natomiast zaprezentowanie problemu z własnej perspektywy, decydowanie $\mathrm{w}$ sprawie przy jednoczesnym przejęciu odpowiedzialności za rozwiązania. Jest szansą na poprawę zakłóconych relacji, a nawet ich odbudowę oraz uzyskanie szybszego zadośćuczynienia niż w przypadku postępowania sądowego. Służy wypracowaniu rozwiązań korzystnych dla obu stron i poszukuje alternatywnych rozwiązań - badając przyczyny konfliktu. Mediacja daje możliwość konstruktywnego podejścia do konfliktu, efektywnego zarządzania konfliktem i traktuje każdy problem jako możliwy do rozwiązania. Bez względu na rodzaj zaistniałego konfliktu, a także rodzaj mediacji (karna, dla nieletnich, rodzinna, rówieśnicza) widoczne są w niej powtarzalne zasady. Dotyczą one dobrowolności - czyli wolności decyzji dotyczącej uczestnictwa w mediacji; bezstronności, w której widoczna jest rola mediatora jako tego, który nie opowiada się za żadną ze stron; neutralności wobec przedmiotu sporu; poufności skutkującej tym, że bez zgody stron treść rozmów nie zostaje ujawniona, a także akceptowalności, która dotyczy zaakceptowania mediatora przez strony ${ }^{44}$.

Mediacja w stopniu znacznie większym niż pozostałe metody rozwiązywania sporów zapewnia respektowanie autonomii stron. Prawidłowo przebiegający proces mediacji wzbudza w stronach poczucie odpowiedzialności za bieg sprawy. Jest to spowodowane świadomością realnego wpływu na ostateczny kształt porozumienia. Strony

40 Agata Gójska, Mediacja w sprawach rodzinnych (Warszawa: Ministerstwo Sprawiedliwości, 2011), 3.

${ }^{41}$ Kodeks postępowania cywilnego (Dz.U. 2005, nr 172, poz. 1438).

${ }_{42}$ Morek, Mediacja w sprawach cywilnych..., 6.

43 Małgorzata Kuć, Wiktymologia (Warszawa: Wydawnictwo C.H. Beck, 2010), 132.

${ }^{44}$ Tamże, 135-136. 
zachowują kontrolę nad tym, czy i jak dojdzie do przezwyciężenia sporu, unikając jednocześnie ryzyka związanego z nieprzewidywalnością rozstrzygnięcia sądowego ${ }^{45}$.

Ewa Grudziewska podkreśla, że celem procesu mediacyjnego będzie rozwiązanie sporu przez zawarcie porozumienia między stronami, zaspokojenie interesów stron, uzyskanie wewnętrznej przemiany stron, nawet jeśli nie dojdzie do porozumienia, możliwe jest np. wybaczenie, wzajemne zrozumienie oraz uwzględnienie wspólnych interesów ${ }^{46}$.

Mediator jako ekspert od procedury, a nie ekspert od rozwiązań, stwarza warunki do przeprowadzenia tego procesu tak, aby strony zrozumiały swoje potrzeby i odchodziły od wzajemnego oskarżania się i obwiniania. Tworzenie warunków współpracy nie jest łatwe, szczególnie wówczas, gdy występują bariery w komunikacji ${ }^{47}$, gdy jedna ze stron lub obydwie stosują taktyki manipulacji psychologicznej czy taktyki presji pozycyjnej (stawianie warunków przez eskalację żądań, radykalne żądanie, stawianie twardych wyborów). Obowiązująca $\mathrm{w}$ mediacji zasada równości sprawia, że strony mają równe prawa i obowiązki oraz że żaden z uczestników nie posiada silniejszej pozycji. Emocjom w mediacji często towarzyszy opór stron (brak postępu we współpracy czy wręcz regresja w procesie zmian), a także wycofanie ze wcześniejszych ustaleń i trzymanie się jednej opcji (następuje wówczas tzw. praca z impasem). Mediator, pracując ze stronami, wykorzystuje wówczas wybrane techniki usprawniające komunikację, do których należy: wstępne zneutralizowanie problemu, normalizowanie, czyli uspokojenie i danie nadziei na wspólne rozwiązanie problemu, powtórzenie i parafraza, dowartościowanie, odzwierciedlenie oraz podsumowanie, konieczne w momencie, gdy konflikt jest wielowątkowy i wymaga przypomnienia głównych punktów wymagających rozwiązania. Mediator, choć nie angażuje się w konflikt, jest osobą bezstronną i neutralną, postrzegany jest często jako osoba, która rozwiąże zaistniały spór. Nie jest on jednak od przedstawiania stronom gotowych rozwiązań, ponieważ to strony mają wypracować wspólnie rozwiązanie kwestii spornych i wprowadzić efekty porozumienia w życie ${ }^{48}$.

45 Anna Pinkowicz, „Mediacja w postępowaniu cywilnym jako skuteczna metoda alternatywnego rozwiązywania sporów, z uwzględnieniem mediacji w sprawach rodzinnych i z zakresu prawa pracy". W: Rozwiązywanie sytuacji konfliktowych..., 383.

46 Ewa Grudziewska, Mediacja sq̨dowa. Alternatywna metoda resocjalizacyjna? (Lublin: Wydawnictwo UMCS, 2010), 70-71.

${ }_{47}$ Linda Heun i Richard Heun opisują następujące bariery w komunikacji: nieostrożność, zniekształcenie motywu, nadmierne zaabsorbowanie sobą, przejawianie zachowań obronnych, brak zaufania, nastawienie do odbiorcy, emocje, różnice językowe, niezgodność przekazów werbalnych i pozawerbalnych, percepcja. Szerzej na ten temat: Linda Heun, Richard E. Heun, Developing Skills for Human Interaction (London: Charles E. Merrill Publishing Co. / A Bell and Howell Co., 1978).

48 Szerzej na ten temat Hanna Karaszewska, „Mediacja jako dobrowolny sposób rozwiązywania konfliktów w rodzinie". W: Horyzonty pedagogiki resocjalizacyjnej. Księga Jubileuszowa Profesora Wiesława Ambrozika, red. Agnieszka Barczykowska, Maciej Muskała (Poznań: Wydawnictwo Naukowe UAM, 2017), 409-423; Hanna Karaszewska, Joanna Rajewska de Mezer, Ewelina Silecka-Marek, „Increasing Role of Mediation in Conflict in the Family”, Studia Edukacyjne 53 (2019). 
Reasumując, zaletą mediacji jest możliwość stosowania jej w różnych dziedzinach życia ${ }^{49}$. Konieczne jest jednak wspólne działanie i przekonanie, że można ją wykorzystać, a przez to:

a. zmniejszyć koszty zarówno stron, jak i państwa,

b. skrócić czas potrzebny na rozwiązanie sporu,

c. oddać spór w ręce stron - czyli osób zainteresowanych jego rozwiązaniem,

d. pozwolić „kontrolować” stronom przebieg tego sporu,

e. zapewnić poufność w trakcie rozwiązywania sporu,

f. działać dla przyszłości stron, a nie koncentrować się tylko na przeszłości,

g. usprawnić komunikację między stronami,

49 Akty prawne regulujące mediacje w Polsce: Regulacje karne: Ustawa z dnia 6 czerwca 1997 r. Kodeks postępowania karnego (Dz.U. 2016, poz. 1749) - regulacja obowiązująca od 1 lipca 2003 r., wprowadzona do Kodeksu postępowania karnego ustawą z dnia 10 stycznia 2003 r. (Dz.U. 2003, nr 17, poz. 155 ze zm.); Ustawa z dnia 6 czerwca 1997 r. Kodeks karny (Dz.U. 2016, poz. 1137 ze zm.); Rozporządzenie Ministra Sprawiedliwości z dnia 7 maja 2015 r. w sprawie postępowania mediacyjnego w sprawach karnych, Warszawa (Dz.U. 2015, poz. 716); Obwieszczenie Ministra Sprawiedliwości z dnia 22 marca 2013 r. w sprawie ogłoszenia jednolitego tekstu rozporządzenia Ministra Sprawiedliwości w sprawie wysokości i sposobu obliczania wydatków Skarbu Państwa w postępowaniu karnym, Warszawa (Dz.U. 2013, poz. 663); Regulacje dotyczące nieletnich: Ustawa z dnia 26 października 1982 r. o postępowaniu w sprawach nieletnich (Dz.U. 2016, poz. 1654); Rozporządzenie Ministra z dnia 18 maja 2001 r. w sprawie postępowania mediacyjnego w sprawach nieletnich (Dz.U. 2001, nr 56, poz. 591); Rozporządzenie Ministra Sprawiedliwości z dnia 13 czerwca 2016 r. w sprawie wysokości i szczegółowych zasad ustalania kosztów postępowania w sprawach nieletnich (Dz.U. 2016, poz. 863); Regulacje cywilne: Ustawa z dnia 17 listopada 1964 r. Kodeks postępowania cywilnego (Dz.U. 2016, poz. 1822 ze zm.) - regulacja obowiązująca od 10 grudnia 2005 r., wprowadzona do Kodeksu postępowania cywilnego ustawą z dnia 28 lipca 2005 r. o zmianie Kodeksu postępowania cywilnego oraz niektórych innych ustaw (Dz.U. 2005, nr 172, poz. 1438), z późniejszymi zmianami, w tym wprowadzonymi ustawą o zmianie niektórych ustaw w związku ze wspieraniem polubownych metod rozwiązywania sporów z dnia 10 września 2015 r. (Dz.U. 2015, poz. 1595); Ustawa z dnia 23 kwietnia 1964 r. Kodeks cywilny (Dz.U. 1964, nr 16, poz. 93 ze zm.); Ustawa z dnia 28 lipca 2005 r. o kosztach sądowych w sprawach cywilnych (Dz.U. 2016, poz. 623 ze zm.); Rozporządzenie Ministra Sprawiedliwości z dnia 20 czerwca 2016 r. w sprawie wysokości wynagrodzenia i podlegających zwrotowi wydatków mediatora w postępowaniu cywilnym, Warszawa, dnia 28 czerwca 2016 r., poz. 921; Rozporządzenie Ministra Sprawiedliwości z dnia 20 stycznia 2016 r. w sprawie prowadzenia listy stałych mediatorów, Warszawa, dnia 28 stycznia 2016 r., poz. 122; Ustawa z dnia 27 lipca 2001 r. Prawo o ustroju sądów powszechnych (Dz.U. z 2016 r., poz. 2062); Ustawa z dnia 23 września 2016 r. o pozasądowym rozwiązywaniu sporów konsumenckich, Warszawa (Dz.U. 2016, poz. 1823); Regulacje administracyjne: Ustawa z dnia 14 czerwca 1960 r. Kodeks postępowania administracyjnego (Dz.U. 2016, poz. 23 ze zm.); Ustawa z dnia 30 sierpnia 2002 r. Prawo o postępowaniu przed sądami administracyjnymi (Dz.U. 2016, poz. 718 ze zm.) - regulacja obowiązująca od 1 czerwca 2017 r., wprowadzona do ustawy Prawo o postępowaniu przed sądami administracyjnymi ustawą z dnia 7 kwietnia 2017 r. (Dz.U. 2017, poz. 935); Rozporządzenie Ministra Spraw Wewnętrznych i Administracji z dnia 2 czerwca 2017 r. w sprawie wysokości wynagrodzenia i podlegających zwrotowi wydatków mediatora w postępowaniu administracyjnym, Warszawa (Dz.U. 2017, poz. 1088); Rozporządzenie Ministra Spraw Wewnętrznych i Administracji z dnia 2 czerwca 2017 r. w sprawie wysokości wynagrodzenia i podlegających zwrotowi wydatków mediatora w postępowaniu przed sądem administracyjnym, Warszawa (Dz.U. 2017, poz. 1087). 
h. poszukiwać przez strony takiego rozwiązania, które przyniesie im obu satysfakcję i poczucie sukcesu,

i. wyeliminować sytuacje stresujące dotyczące konkretnego sporu ${ }^{50}$.

Wskazując na pozytywne aspekty mediacji, podkreśla się zaletę, którą jest mniejsze prawdopodobieństwo stygmatyzacji stron konfliktu ${ }^{51}$. Anna Kalisz, wskazując na istotę mediacji, stwierdza, że jest ona przykładem niewładczej ingerencji w spór osoby trzeciej, która pośredniczy w dojściu do porozumienia. Poprzez racjonalną perswazję likwiduje rozbieżności między stanowiskami stron, nie przyznając racji żadnej z nich ${ }^{52}$. Mediacja konkretyzuje potrzeby jednostek, pozwala na podjęcie próby polubownego rozwiązania konfliktu, wpływa na poszukiwanie rozwiązań, które będą korzystne w przyszłości. Daje też możliwość przerwania przedłużającego się konfliktu i wypracowania reguł postępowania między stronami.

\section{Zakończenie}

Powstanie i postrzeganie mediacji jako procedury stosowanej zgodnie z rozwiązaniami prawnymi wymagało czasu. Źródła historyczne jednoznacznie wskazują na istnienie mediacji jako sposobu rozwiązywania sporu na przestrzeni wieków, ale nie była ona tak rozpowszechniona, jak sądy polubowne. Dostrzeżenie jej zalet nie jest domeną naszych czasów. Pojawienie się na przestrzeni wieków mediacji jako sposobu rozwiązywania konfliktu przez strony pokazuje, jak ważną rolę odegrała zarówno w sporach państwowych, gospodarczych, jak i po prostu w sporach międzyludzkich, dotykających spraw sąsiedzkich czy rodzinnych. Ten sposób szukania rozwiązania, ukształtowany przez doświadczenia ludzi z różnych wieków czy różnych kultur, sprawdza się do dnia dzisiejszego. Rozwijająca się idea mediacji pozwoliła na odejście od sposobu myślenia, który nakazywał rozwiązanie za strony konfliktu. Wypracowana procedura umożliwiła oddanie konfliktu stronom i stworzenie dla nich warunków, w których mogą przedstawić swoje racje i poszukać dla siebie korzystnego rozwiązania - bez oceny i wskazywania rozwiązań przez mediatora. Również jego rola uległa modyfikacjom. Wprawdzie śmiało można stwierdzić, iż nadal utrzymuje się przekonanie, że powinna być to osoba ciesząca się zaufaniem stron konfliktu, bezstronna i sprawiedliwa, ale bycie mediatorem nie zależy już od pozycji majątkowej, społecznej, ale od przygotowania do pełnienia tej funkcji. Mediacja stwarzała i stwarza

${ }^{50}$ Szerzej na temat porównania efektywności sądu, arbitrażu i mediacji: Sylwester Pieckowski, Mediacja w sprawach gospodarczych (Warszawa: Ministerstwo Sprawiedliwości, 2012), 4.

${ }^{51}$ Kuć, Wiktymologia, 142.

${ }^{52}$ Anna Kalisz, „Praktyka mediacji w polskim porządku prawnym (na tle rozwiązań amerykańskich)", Studia Iuridica Lublinensia 1 (2003), 87. 
możliwość odciążenia sądownictwa, ale nadal - choć przecież istnieje w rozwiązaniach prawnych - wymaga społecznej promocji. Jak pisze Dagmara Słomińska-Butowski, skuteczność mediacji nadal jest oceniana na podstawie liczby zawartych ugód. Jednak statystyki nie obejmują informacji na temat wyciszenia emocji stron czy stworzenia warunków do spokojnej rozmowy o sporze oraz porozumienia i sposobu najbardziej korzystnego dla obu stron ${ }^{53}$. Zatem oprócz kwestii formalnych, które są niezbędne zarówno w sytuacji kierowania, kwalifikowania spraw do mediacji, odpowiedniej procedury mediacyjnej, jak i standardów postępowania - warto pamiętać o podstawowym jej założeniu, a mianowicie, że służyć ma ona stronom, a jeśli będzie realizowała ten cel, to wpłynie także na harmonię społeczną, tak ważną dla ludzi w dawnych i obecnych czasach.

Streszczenie: Mediacja stanowi proces oparty na zasadzie dobrowolności, który powinien zmierzać do rozwiązania konfliktu między stronami. Jako forma interwencji w spór stwarza możliwość porozumienia się między stronami bez udziału sądu. Wypracowane podczas procedury mediacji rozwiązania ukierunkowują strony na przyszłość i pozwalają zaspokoić interesy obu stron. Praca porusza problem historycznych uwarunkowań powstania mediacji, jej definiowania na przestrzeni wieków. W artykule opisane zostały także sądy polubowne jako te, które rozstrzygały spory od czasów nowożytnych aż do współczesnych. Przede wszystkim skoncentrowano się na mediacji, podkreślono jej istotę, a także jej możliwości zastosowania w poszczególnych państwach. Mediacja prezentowana jest jako ważna metoda, pozwalająca stronom decydować, jak rozwiązać konflikt. Artykuł zawiera informacje dotyczące historii jej rozwoju, a także podstawy prawne, które dały początek jej rozpowszechnieniu w kraju i na świecie. Oprócz historycznych uwarunkowań powstania mediacji opisano zasady obowiązujące podczas prowadzenia mediacji, a także podstawowe problemy, które pojawiają się w trakcie jej prowadzenia.

Słowa kluczowe: mediacja, konflikt, spór, arbitraż, porozumienie, ugoda, mediator

\section{Bibliografia}

Barrett, Jerome T., Barrett, Joseph P. A History of Alternative Dispute Resolution. San Francisco: CA: John Wiley and Sons, Inc., 2004.

Bystroń, Jan S. Dzieje obyczajów w dawnej Polsce. Wiek XVI-XVIII. Warszawa: Trzaska, Evert i Michalski, 1994.

Durkheim, Emile. Socialism and Saint Simone, London: Routledge \& New Haven: Kegan Paul, 1959. Falkiewicz, Krzysztof, Kwaśnicki, Radosław L. „Arbitraż i mediacja w świetle najnowszej nowelizacji Kodeksu postępowania cywilnego". Przegląd Prawa Handlowego (11) 2005, 32-37.

53 Dagmara Słomińska-Butowski, „Bariery stosowania mediacji w środowisku prokuratury”. W: Rozwiązywanie sytuacji konfliktowych..., 405. 
Gmurzyńska, Ewa. Mediacja w sprawach cywilnych w amerykańskim systemie prawnym. Zastosowanie w Europie i w Polsce, Warszawa: C.H. Beck, 2007.

Gójska, Agata. Mediacja w sprawach rodzinnych. Warszawa: Ministerstwo Sprawiedliwości, 2011.

Grudziewska, Ewa. Mediacja sądowa. Alternatywna metoda resocjalizacyjna? Lublin: Wydawnictwo UMCS, 2010.

Heun, Linda, Heun, Richard E. Developing Skills for Human Interaction. London: Charles E. Merrill Publishing Co. / A Bell and Howell Co., 1978.

Kaleta, Roman. Sensacje $z$ dawnych lat. Wrocław: Ossolineum, 1980.

Kalisz, Anna. „Praktyka mediacji w polskim porządku prawnym (na tle rozwiązań amerykańskich)”. Studia Iuridica Lublinensia 1 (2003), 85-95.

Karaszewska, Hanna. „Mediacja jako dobrowolny sposób rozwiązywania konfliktów w rodzinie”. W: Horyzonty pedagogiki resocjalizacyjnej. Ksiega Jubileuszowa Profesora Wiesława Ambrozika, red. Agnieszka Barczykowska, Maciej Muskała. Poznań: Wydawnictwo Naukowe UAM, 2017, 409-423.

Karaszewska, Hanna, Rajewska de Mezer, Joanna, Silecka-Marek, Ewelina. „Increasing Role of Mediation in Conflict in the Family”. Studia Edukacyjne 53 (2019), 285-299.

Kitowicz, Jędrzej. Opis obyczajów za panowania Augusta III, oprac. R. Pollak. Wrocław: Wydawnictwo Zakładu Narodowego im. Ossolińskich, 1951.

Klityńska, Pamela. „Myśl Konfucjusza”. ACTA ERASMIANA XIII 76 (2016), 73-85.

Kordasiewicz, Stanisław. „Historyczna i międzynarodowa perspektywa mediacji”. W: Mediacje. Teoria i praktyka, red. Ewa Gmurzyńska, Rafał Morek. Warszawa: Wolters Kluwer Polska, 2014, 35 i nast.

Kuchowicz, Zbigniew. Obyczaje staropolskie XVII-XVIII wieku. Łódź: Wydawnictwo Łódzkie, 1975. Kuć, Małgorzata. Wiktymologia. Warszawa: Wydawnictwo C.H. Beck, 2010.

Mediacje. Teoria i praktyka, red. Ewa Gmurzyńska, Rafał Morek. Warszawa: Wolters Kluwer, 2014.

Modrzewski, Andrzej F. Dzieła wszystkie. Mowy, t. II, red. Stefan Żółkiewski. Warszawa: Państwowy Instytut Wydawniczy, 1954.

Moniuszko, Adam, Rosner, Anna. „Historia polubownego rozwiązania sporów na ziemiach polskich. Zarys problematyki”. W: Mediacje. Teoria i praktyka, red. Ewa Gmurzyńska, Rafał Morek. Warszawa: Wolters Kluwer Polska, 2014, 35 i nast.

Morek, Rafał. Mediacja w sprawach cywilnych. Stan prawny na 1 grudnia 2012 r. Warszawa: Ministerstwo Sprawiedliwości, 2012.

Mroczyński-Szmaj, Łukasz. „Arbiter i arbitraż - na przestrzeni dziejów. Historia polskiego sądownictwa polubownego do 1989 r.". Zeszyty Naukowe Uniwersytetu Rzeszowskiego. Seria Prawnicza. Prawo 14 (82) (2014), 129-144.

Myrcha, Marian A. Sądy polubowne w prawie kanonicznym. Studium prawno-porównawcze. Lublin: Rozprawy Wydziału Kanoniczno-Teologicznego KUL, 1948.

Pieckowski, Sylwester. Mediacja w sprawach gospodarczych. Warszawa: Ministerstwo Sprawiedliwości, 2012.

Pinkowicz, Anna. „Mediacja w postępowaniu cywilnym jako skuteczna metoda alternatywnego rozwiązywania sporów, z uwzględnieniem mediacji w sprawach rodzinnych i z zakresu prawa pracy”. W: Rozwiazywanie sytuacji konfliktowych w wymiarze jednostkowym i społecznym, red. Martyna Plucińska. Poznań: Wydawnictwo Naukowe Wydziału Nauk Społecznych Uniwersytetu im. Adama Mickiewicza, 2014, 377-390.

Rękas, Agnieszka. Czy tylko sąd rozstrzygnie o sporze? Mediacja i sądownictwo polubowne. Informator o alternatywnych sposobach rozwiązywania sporów. Warszawa: Europejski Fundusz Społeczny, 2010. 
Roberts Callister, Ronda, Wall, James A., Jr. „Japanese Community and Organizational Mediations”. The Journal of Conflict Resolution 2 (41) (1997), April, 313-314.

Rosner, Anna. „Sędziowie i urzędnicy sądów pokoju w Księstwie Warszawskim”. Przegląd Historyczny 4 (79) (1988), 659-682.

Simmel, Georg. Socjologia. Warszawa: PWN, 1975.

Sławiński, Roman. Konfucjanizm i jego współczesne interpretacje. Warszawa: ASKON, 2013.

Słomińska-Butowski, Dagmara. „Bariery stosowania mediacji w środowisku prokuratury”. W: Rozwiązywanie sytuacji konfliktowych $w$ wymiarze jednostkowym i społecznym, red. Martyna Plucińska. Poznań: Wydawnictwo Naukowe Wydziału Nauk Społecznych Uniwersytetu im. Adama Mickiewicza, 2014, 405-418.

Słownik języka polskiego, red. nauk. Mieczysław Szymczak. Warszawa: PWN, 1998.

Sobieraj, Michał. Filozofia Konfucjusza. Olsztyn 2005 (wersja PDF).

Sondel, Janusz. Słownik łacińsko-polski dla prawników i historyków. Kraków: Universitas, 2003.

Sójka-Zielińska, Katarzyna. Drogi i bezdroża prawa. Szkice z dziejów kultury prawnej Europy. Wrocław: Ossolineum, 2010.

Szczepaniak, Paweł. Sprawiedliwość naprawcza w resocjalizacji więźniów. Warszawa: Uniwersytet Warszawski. Instytut Profilaktyki Społecznej i Resocjalizacji, 2016.

Świrgoń-Skok, Renata, Arkuszewska, Aneta. „Wpływ alternatywnych sposobów rozwiązywania sporów na efektywność ochrony prawnej”. Zeszyty Naukowe KUL 60 (2017), 3 (239), 243-259.

Tazbir, Janusz. Święci, grzesznicy i kacerze. Warszawa: Wiedza Powszechna, 1959.

Wysocka-Fronczek, Marta. „Dlaczego kieruję sprawy do postępowania mediacyjnego?”. Prokuratura i Prawo 2 (2011), 145-160.

Yao, Xinzhong. Konfucjanizm. Wprowadzenie. Kraków: Wydawnictwo Uniwersytetu Jagiellońskiego, 2009.

Zajączkowska, Maria J. „Sposoby komunikowania się mediatora ze stronami w przyjętych strategiach mediacyjnych". W: Rozwiązywanie sytuacji konfliktowych w wymiarze jednostkowym i społecznym, red. Martyna Plucińska. Poznań: Wydawnictwo Naukowe Wydziału Nauk Społecznych Uniwersytetu im. Adama Mickiewicza, 2014, 327-364.

Zienkiewicz, Adam. „Mediator w sprawach cywilnych”. Rejent 5 (2005), 137-152.

Zienkiewicz, Adam. Studium mediacji. Od teorii ku praktyce. Warszawa: Difin, 2007.

Żołnierczuk, Mieczysław. Rzymskie sądownictwo polubowne (okres przedklasyczny i klasyczny). Lublin: UMCS, 1978.

Akty prawne:

Kodeks postępowania cywilnego (Dz.U. 2005, nr 172, poz. 1438).

Kodeks postępowania karnego z 10 stycznia 2003 roku (Dz.U. 2003, nr 17, poz. 155).

Obwieszczenie Ministra Sprawiedliwości z dnia 22 marca 2013 r. w sprawie ogłoszenia jednolitego tekstu rozporządzenia Ministra Sprawiedliwości w sprawie wysokości i sposobu obliczania wydatków Skarbu Państwa w postępowaniu karnym, Warszawa (Dz.U. 2013, poz. 663).

Rozporządzenie Ministra Spraw Wewnętrznych i Administracji z dnia 2 czerwca 2017 r. w sprawie wysokości wynagrodzenia i podlegających zwrotowi wydatków mediatora w postępowaniu przed sądem administracyjnym, Warszawa (Dz.U. 2017, poz. 1087).

Rozporządzenie Ministra Spraw Wewnętrznych i Administracji z dnia 2 czerwca 2017 r. w sprawie wysokości wynagrodzenia i podlegających zwrotowi wydatków mediatora w postępowaniu administracyjnym, Warszawa (Dz.U. 2017, poz. 1088). 
Rozporządzenie Ministra Sprawiedliwości z dnia 7 maja 2015 r. w sprawie postępowania mediacyjnego w sprawach karnych, Warszawa (Dz.U. 2015, poz. 716).

Rozporządzenie Ministra Sprawiedliwości z dnia 20 stycznia 2016 r. w sprawie prowadzenia listy stałych mediatorów, Warszawa (Dz.U. 2016, poz. 122).

Rozporządzenie Ministra Sprawiedliwości z dnia 13 czerwca 2016 r. w sprawie wysokości i szczegółowych zasad ustalania kosztów postępowania w sprawach nieletnich (Dz.U. 2016, poz. 863).

Rozporządzenie Ministra Sprawiedliwości z dnia 20 czerwca 2016 r. w sprawie wysokości wynagrodzenia i podlegających zwrotowi wydatków mediatora w postępowaniu cywilnym, Warszawa (Dz.U. 2016, poz. 921).

Rozporządzenie Ministra z dnia 18 maja 2001 r. w sprawie postępowania mediacyjnego w sprawach nieletnich (Dz.U. 2001, nr 56, poz. 591).

Ustawa z dnia 14 czerwca 1960 r. Kodeks postępowania administracyjnego (Dz.U. 2016, poz. 23 ze zm.).

Ustawa z dnia 23 kwietnia 1964 r. Kodeks cywilny (Dz.U. 1964, nr 16, poz. 93 z późn. zm.).

Ustawa z dnia 17 listopada 1964 r. Kodeks postępowania cywilnego (Dz.U. 2016, poz. 1822 ze zm.).

Ustawa z dnia 26 października 1982 r. o postępowaniu w sprawach nieletnich (Dz.U. 2016, poz. 1654).

Ustawa z dnia 6 czerwca 1997 r. Kodeks karny (Dz.U. 2016, poz. 1137 ze zm.).

Ustawa z dnia 6 czerwca 1997 r. Kodeks postępowania karnego (Dz.U. 2016, poz. 1749).

Ustawa z dnia 27 lipca 2001 r. Prawo o ustroju sądów powszechnych (Dz.U. 2016, poz. 2062).

Ustawa z dnia 30 sierpnia 2002 r. Prawo o postępowaniu przed sądami administracyjnymi (Dz.U. 2016, poz. 718 ze zm.).

Ustawa z dnia 28 lipca 2005 r. o kosztach sądowych w sprawach cywilnych (Dz.U. 2016, poz. $623 \mathrm{ze} \mathrm{zm}$.).

Ustawa z dnia 23 września 2016 r. o pozasądowym rozwiązywaniu sporów konsumenckich, Warszawa (Dz.U. 2016, poz. 1823). 